\section{'Ovation' Strawberry}

\author{
K.S. Lewers, ${ }^{1}$ J.M. Enns, S.Y. Wang, J.L. Maas, G.J. Galletta, and \\ S.C. Hokanson ${ }^{2}$ \\ U.S. Department of Agriculture, AgriculturalResearch Service, Fruit Laboratory, \\ Beltsville, MD 20705
}

\section{J.R. Clark}

Department of Horticulture, 316 Plant Science, University of Arkansas, Fayetteville, AR 72701-1201

\section{K. Demchak}

Department of Horticulture, 0107A Tyson Building, Pennsylvania State University, University Park, PA 16802

\section{R.C. Funt}

Department of Horticulture and Crop Science, Kottman Hall, 2021 Coffey Road, Ohio State University, Columbus, OH 43210-1086

\section{S.A. Garrison}

Rutgers University, Bridgeton, NJ 08302

\section{G.L. Jelenkovic}

Plant Science, Rutgers University, New Brunswick, NJ 08901

\section{G.R. Nonnecke}

Department of Horticulture, 106 Department of Horticulture Hall, Iowa State University, Ames, IA 50011-1100

\section{P.R. Probasco}

Rutgers Cooperative Extension of Salem County, 51 Cheney Road, Suite 1, Woodstown, NJ 08098

\section{B.J. Smith}

U.S. Department of Agriculture, Agricultural Research Service, Small Fruit Research Station, Poplarville, MS 39470

\section{B.R. Smith}

Plant and Earth Science Department, 410 South 3rd Street, University of Wisconsin, River Falls, WI 54022

\section{C.A. Weber}

Department of Horticultural Sciences, 630 West North Street, Cornell UniversityNew York State Agricultural Experiment Station, Geneva, NY 14456

Additional index words. Fragaria $\times$ ananassa, fruit breeding, Phytophthora fragariae, Colletotrichum, red stele, anthracnose

'Ovation', a June-bearing strawberry (Fragaria $\times$ ananassa Duch. ex Rozier) cultivar, was introduced for propagation to nurseries

\footnotetext{
Received for publication 15 Dec. 2003. Accepted for publication 18 Apr. 2004. We would like to thank Ronghui Yang, Kate Salazar, Tina Sphon, and Tad Sonstagard for SSR profiling; Kate Rappaport for meristem culture and virus indexing; Sam Garrett and Mchezaji Axum for assisting with screening for red stele resistance; Wanda S. Elliott for anthracnose resistance screening; Mary Camp for data analysis consultation; and Kathy Haynes, Talo Pastor-Corrales, John Stommel, Freddi Hammerschlag, and Jim Spiers plus the anonymous reviewers for their helpful comments.

${ }^{1}$ Corrresponding author; e-mail lewersk@ba.ars. usda.gov.

${ }^{2}$ Present address: Dept. of Hort. Sci., 1970 Folwell Ave., Univ. of Minnesota, St. Paul, MN 55108.
}

HortScience Vol. 39(7) December 2004 in January 2003 by the U.S. Department of Agriculture-Agricultural Research Service (USDA-ARS). 'Ovation' was selected for its exceptionally late fruiting season; outstanding plant vigor and ease of propagation; attractive, symmetrical, large firm fruit with good color and flavor; resistance to red-stele root-rot disease (incited by Phytophthora fragariae C.J. Hickman var. fragariae); and moderate resistance to anthracnose fruit and crown rots (caused by Colletotrichumacutatum J.H. Simmonds). Most years, in the plasticulture production system in Maryland, 'Ovation' was among the top-yielding selections and cultivars, yielding as well as 'Allstar'. In the advanced matted row system in Maryland, 'Ovation' fruit size and quality remained high while yields were slightly below average. Evaluation in other regions indicates that exceptionally late fruiting season and good quality fruits make 'Ovation' a good season extender even in locations and production systems where yield is just average. 'Ovation' is suggested for trial in the mid-Atlantic U.S., adjacent regions, and parts of the midwestern U.S. as a high-quality, large-fruited cultivar to extend growers' strawberry production into July. 'Ovation' was named, not only because the cultivar marks the end of strawberry production season in these regions, but also to honor the long and productive career of the late Gene Galletta.

\section{Origin and Seedling Selection}

'Ovation', tested as B440 N, was a strawberry seedling from a cross of 'Lateglow' $x$ 'Etna' made by G.J. Galletta at Beltsville, Md., in 1989. Seedlings from this cross were screened for resistance to a five-race composite of $P$. fragariae var. fragariae in a greenhouse test at Beltsville during the winter of 1989-1990, using the method of Scott et al. (1975). Surviving seedlings were transplanted in spring 1990 to a field on the Beltsville Agricultural Research Center farm. 'Ovation' was selected in 1991 by G.J. Galletta and J.M. Enns. Loss of P. fragariae isolates prevented confirmation of resistance. 'Ovation' was evaluated at Beltsville during the period 1993-2003, and was sent to cooperating scientists in Arkansas, Iowa, New Jersey, New York, Ohio, Pennsylvania, and Wisconsin for performance evaluation.

\section{Technical Description}

Plants. 'Ovation' produces a dense plant with numerous long petioles. Petioles are light green with brownish-red streaks, a medium

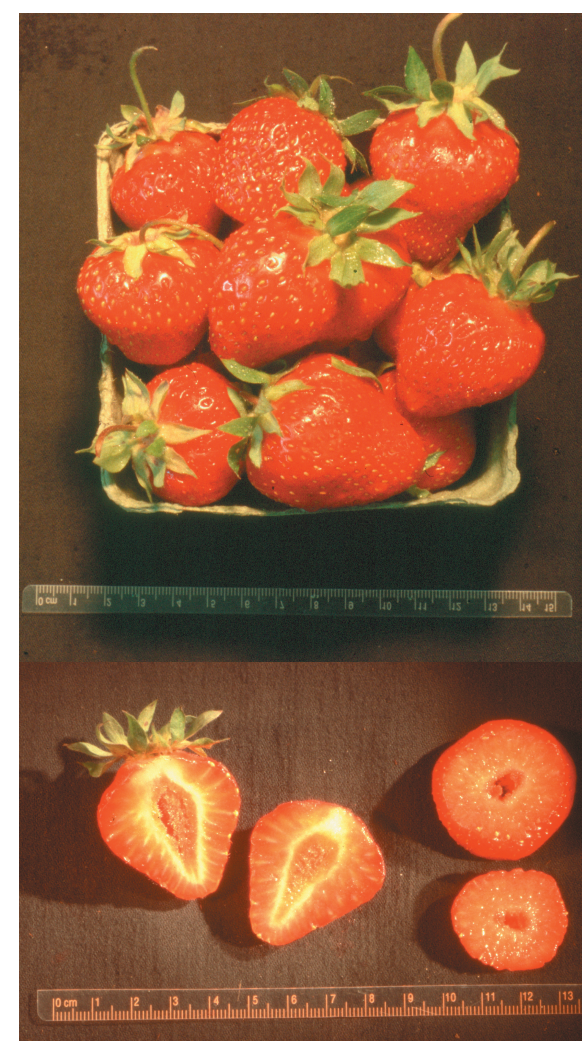

Fig. 1. 'Ovation' berries. 
deep stem groove and perpendicular hairs. Leaves are uniformly comprised of three leaflets. Generally, no leaf bracts are found; however, when present, they can range from one or two leaflets to one or two cupped stipules and occur within $5 \mathrm{~cm}$ of the leaf origin. Leaflet serration begins one-quarter to one-third from the base of the terminal leaflet with the terminal leaflets having about 26 serrations. They are dentate, medium in length and uneven in size, with the terminal leaflet tipped shorter and smaller than those adjacent. Individual leaflets are curled, medium to light green in color, with the leaflet tips being cupped. The terminal petiolule is short. The terminal leaflet base occurs at about a $45^{\circ}$ angle. The interveinal lamina is smooth to slightly rugose. Stolons are medium red dorsally where exposed to the sun and green where shaded and on ventral surfaces.

Fruit. Fruit are similar in size most years to those of 'Allstar, 'Northeaster', and 'Chandler', but larger than those of 'Latestar' (Table 1). Fruit are firm, with reddish-orange, slightly tender, glossy skin (Fig. 1). Achenes, which are flush to slightly recessed to the fruit surface, are predominantly yellow, but can range to completely red. Primary fruit are uniformly wedge shaped, being nearly as wide as long. Later fruit assume a more conic-wedge to strictly conic shape. Fruits can have a slight neck that is pigmented. The calyx can possess alternately reflexed and relaxed sepals to completely reflexed sepals. Interior flesh is orange-red at the distal end, with a white ring around a slight core at the proximal end. Flesh is creamy, subacid with an aromatic overtone.

Molecular marker profile. 'Ovation' was characterized with two simple sequence repeat (SSR) molecular markers, ARSFL-4 and ARSFL-8 as described in Ashley et al. (2003). The reaction products obtained using ARSFL-4 were 172 and $187 \mathrm{bp} \mathrm{long}$; those obtained using ARSFL- 8 were 304 bp long.

\section{Evaluation}

Production. Each year from 1993 through 2003, 'Ovation' was evaluated with other selections and cultivars on the Beltsville Agricultural Research Center farm on Rumford series, course-loamy, siliceous, thermic Typic Hapludults soils. Evaluations were made in a randomized complete block design with one replication in each of four blocks in advanced matted-row and plasticulture production systems (Black et al., 2002). Both are annual systems using raised beds with trickle irrigation $7 \mathrm{~cm}$ below the surface. The plasticulture system utilizes black plastic mulch. Six-plant plots were established in August previous to each evaluation year. The advanced matted-row system used a killed hairy vetch, crimson clover, and cereal rye mix as a cover-crop mulch. In May previous to each evaluation year, four plants were used to establish $1.5-\mathrm{m}$ plots. Fertigation supplied additional nutrients at $34 \mathrm{~kg} \cdot \mathrm{ha}^{-1} \mathrm{~N}$ per year on soils with existing high levels of $\mathrm{P}$ and $\mathrm{K}$, and soil $\mathrm{pH}$ at 6.3 to 6.5 . No fungicides are used in either production system. Frost protection of spring flowers was provided in the form of overhead sprinkler irrigation when temperatures dropped below $1{ }^{\circ} \mathrm{C}$. Plants in each plot were evaluated through the season for plant stand (number of plants or percentage plot filled), vigor, disease, and runner production. During the fruiting season, plots were evaluated twice weekly for yield, fruit disease, marketability and fruit weight. In addition, fruit from each plot were subjectively evaluated twice for symmetry, appearance, firmness, skin toughness (resistance to abrasion when rubbed with a thumb), internal and external color, and flavor. For each trait, separate analyses of variance were performed within location, culture system, and year. Data analyses for subjective traits are not presented. Yield analyses were done on absolute yields, then converted to $\mathrm{kg} \cdot \mathrm{ha}^{-1}$ for site and year comparisons. Means were compared with Duncan's multiple range test at $P \leq 0.05$.

\section{Performance}

'Ovation' flowered and fruited in Beltsville, Maryland four to ten days later than the popular late-season standard, 'Jewel'. Yield of 'Ovation' in the advanced matted-row production system was slightly below average, ranging from about 16,000 to $19,000 \mathrm{~kg} \cdot \mathrm{ha}^{-1}$, and generally was the highest or among the highest in plasticulture production, generally ranging from 27,000 to 35,000 $\mathrm{kg} \cdot \mathrm{ha}^{-1}$ (Table 2). Yields were comparable to those of the very productive cultivar, 'Allstar', and greater than or equal to 'Chandler', the standard cultivar for eastern plasticulture production. Fruit weight of 'Ovation' was generally high at Beltsville (Table 1) in both production systems, and fruit was consistently attractive in subjective evaluations. The late season, large attractive fruit, and potential high yield combine to make 'Ovation' a viable season extender, especially in the plasticulture production system, which is increasing in use in the mid-Atlantic and midwestern U.S. regions.

\section{Area of Adaptation}

Arkansas. 'Ovation' was evaluated in 2001 in the traditional matted-row production system. Yield was among the highest of the cultivars tested and was similar to yield from 'Northeaster' and 'Earliglow'. The fruit were attractive, and size averaged $10.4 \mathrm{~g}$, about the same size as 'Cardinal' fruit.

Iowa. 'Ovation' was evaluated at the Iowa State University Horticulture Station located in rural Ames, Iowa during the 2003 growing season. Conventional cultural practices were used for matted-row culture. Crowns were planted

Table 1. Average fruit weight (g) of 'Ovation' strawberry and standard cultivars in two production systems during 4 or 5 production years in Beltsville, Md.

\begin{tabular}{|c|c|c|c|c|c|c|c|}
\hline $\begin{array}{l}\text { Production } \\
\text { system }\end{array}$ & $\mathrm{N}^{\mathrm{z}}$ & 'Ovation' & 'Latestar' & 'Allstar' & 'Northeaster' & 'Chandler' & LSD \\
\hline \multicolumn{8}{|l|}{ Plasticulture } \\
\hline 1999 & 30 & $13.1 \mathrm{a}^{\mathrm{y}}$ & $12.3 \mathrm{a}$ & $13.5 \mathrm{a}$ & $13.1 \mathrm{a}$ & $11.7 \mathrm{a}$ & 2.1 \\
\hline 2000 & 22 & $15.0 \mathrm{a}$ & --- & $13.9 \mathrm{a}$ & $15.0 \mathrm{a}$ & $12.8 \mathrm{~b}$ & 2.0 \\
\hline 2001 & 20 & $17.5 \mathrm{a}$ & $12.7 \mathrm{~b}$ & $14.9 \mathrm{a}$ & $17.2 \mathrm{a}$ & $15.5 \mathrm{a}$ & 3.0 \\
\hline 2002 & 26 & $16.9 \mathrm{a}$ & $10.3 \mathrm{~b}$ & $12.2 \mathrm{~b}$ & $12.5 \mathrm{~b}$ & $12.0 \mathrm{~b}$ & 2.9 \\
\hline $2003^{x}$ & 24 & $14.9 \mathrm{a}$ & --- & $11.2 \mathrm{~b}$ & $10.9 \mathrm{~b}$ & $9.4 \mathrm{~b}$ & 3.3 \\
\hline Mean & & 15.5 & 11.8 & 13.1 & 13.7 & 12.3 & \\
\hline \multicolumn{8}{|c|}{ Advanced matted-row } \\
\hline 2000 & 24 & $14.3 \mathrm{a}$ & $15.3 \mathrm{a}$ & $14.3 \mathrm{a}$ & $14.1 \mathrm{a}$ & --- & 1.6 \\
\hline 2001 & 23 & $18.5 \mathrm{a}$ & $13.5 \mathrm{c}$ & $14.7 \mathrm{bc}$ & $15.8 \mathrm{~b}$ & $13.4 \mathrm{c}$ & 2.2 \\
\hline 2002 & 28 & $13.1 \mathrm{bc}$ & $11.4 \mathrm{~cd}$ & $15.9 \mathrm{a}$ & $14.1 \mathrm{ab}$ & $10.4 \mathrm{~d}$ & 2.0 \\
\hline 2003 & 20 & $9.8 \mathrm{a}$ & --- & $9.7 \mathrm{a}$ & $10.5 \mathrm{a}$ & $8.5 \mathrm{a}$ & 2.6 \\
\hline Mean & & 13.9 & 13.4 & 13.7 & 13.6 & 10.8 & \\
\hline
\end{tabular}

${ }^{2} \mathrm{~N}=$ number of cultivars and selections compared in each production system for each year

${ }^{y}$ Letters to the right of fruit size values indicate significant differences $(P=0.05)$ among all cultivars and selection tested (many of which are not reported here) for each year and production system.

${ }^{x}$ Fruit size in 2003 was low due to record rain and cool temperatures.

Table 2. Yields $\left(\mathrm{kg} \cdot \mathrm{ha}^{-1}\right)$ of 'Ovation' strawberry and standard cultivars in two production systems during 4 or 5 production years in Beltsville, Md.

\begin{tabular}{|c|c|c|c|c|c|c|c|}
\hline $\begin{array}{l}\text { Production } \\
\text { system }\end{array}$ & $\mathrm{N}^{\mathrm{z}}$ & 'Ovation' & 'Latestar' & 'Allstar' & 'Northeaster' & 'Chandler' & LSD \\
\hline \multicolumn{8}{|l|}{ Plasticulture } \\
\hline 1999 & 30 & $35,447 b^{y}$ & $50,900 \mathrm{a}$ & $37,881 \mathrm{~b}$ & $33,921 \mathrm{~b}$ & $30,792 \mathrm{~b}$ & 7,740 \\
\hline 2000 & 22 & $31,730 \mathrm{a}$ & -- & $30,255 \mathrm{ab}$ & $24,992 \mathrm{~b}$ & $23,678 \mathrm{~b}$ & 6,737 \\
\hline 2001 & 20 & $27,376 \mathrm{ab}$ & $17,408 \mathrm{c}$ & $29,203 \mathrm{a}$ & $19,270 \mathrm{c}$ & $20,444 \mathrm{bc}$ & 7,084 \\
\hline 2002 & 26 & $30,327 \mathrm{a}$ & $13,781 \mathrm{~d}$ & $23,416 b$ & $14,293 \mathrm{~cd}$ & $19,263 \mathrm{bc}$ & 5,097 \\
\hline $2003^{x}$ & 24 & $8,056 \mathrm{a}$ & -- & $10,076 \mathrm{a}$ & $9,231 \mathrm{a}$ & $2,931 \mathrm{~b}$ & 4,339 \\
\hline Mean & & 26,587 & 27,363 & 26,166 & 20,341 & 19,422 & \\
\hline \multicolumn{8}{|c|}{ Advanced matted-row } \\
\hline 2000 & 24 & $18,438 \mathrm{~b}$ & $33,071 \mathrm{a}$ & $24,781 \mathrm{~b}$ & $20,115 b$ & --- & 3,922 \\
\hline 2001 & 23 & $19,235 \mathrm{bc}$ & $22,909 \mathrm{~b}$ & $22,769 \mathrm{~b}$ & $17,509 \mathrm{c}$ & $27,843 \mathrm{a}$ & 3,769 \\
\hline 2002 & 28 & $15,639 \mathrm{c}$ & $31,291 \mathrm{a}$ & $25,478 \mathrm{~b}$ & $22,603 \mathrm{~b}$ & $21,750 \mathrm{~b}$ & 3,728 \\
\hline 2003 & 20 & $1,558 \mathrm{~b}$ & --- & $5,576 \mathrm{a}$ & $7,043 \mathrm{a}$ & $6,990 \mathrm{a}$ & 2,270 \\
\hline Mean & & 13,718 & 29,091 & 19,651 & 16,817 & 18,861 & \\
\hline
\end{tabular}

${ }^{\mathrm{z}} \mathrm{N}=$ number of cultivars and selections compared in each production system for each year

${ }^{y}$ Letters to the right of yield values indicate significant differences $(P=0.05)$ among all cultivars and selection tested (many of which are not reported here) for each year and production system.

${ }^{x}$ Yield in 2003 was low due to record rain, cool temperatures, and a deer problem. 
Table 3. Fruit antioxidant capacity (ORAC) ( $\mu \mathrm{mol} \mathrm{TE} / \mathrm{g}$ of fresh weight), total anthocyanins content (mg/100 $\mathrm{g}$ fresh weight), total phenolics content ( $\mathrm{mg} / 100 \mathrm{~g}$ fresh weight), soluble solids (SSC) (\%), titratable acids (TA) (\%), and ratio of soluble solids content to titratable acids content (SSC/TA) of fruit of 'Ovation' strawberry, and three standard cultivars grown in two production systems, advanced matted-row (M) and plasticulture (P), in Beltsville, Md.

\begin{tabular}{lcrrrrr}
\hline Parameter & Production system & 'Ovation' & 'Latestar' & 'Allstar' & 'Northeaster' & LSD $^{2}$ \\
\hline ORAC & $\mathrm{M}$ & $32.0 \mathrm{a}$ & $25.9 \mathrm{~b}$ & $14.3 \mathrm{c}$ & $19.2 \mathrm{bc}$ & 7.1 \\
& $\mathrm{P}$ & $29.6 \mathrm{a}$ & $22.1 \mathrm{~b}$ & $16.6 \mathrm{~b}$ & $21.0 \mathrm{~b}$ & 5.9 \\
Anthocyanin & $\mathrm{M}$ & $31.3 \mathrm{a}$ & $27.9 \mathrm{ab}$ & $17.3 \mathrm{c}$ & $20.0 \mathrm{bc}$ & 7.8 \\
& $\mathrm{P}$ & $28.2 \mathrm{a}$ & $22.8 \mathrm{ab}$ & $16.7 \mathrm{~b}$ & $22.9 \mathrm{ab}$ & 7.3 \\
Phenolics & $\mathrm{M}$ & $198.0 \mathrm{a}$ & $133.6 \mathrm{~b}$ & $114.3 \mathrm{~b}$ & $110.2 \mathrm{~b}$ & 36.7 \\
& $\mathrm{P}$ & $181.4 \mathrm{a}$ & $135.6 \mathrm{ab}$ & $114.4 \mathrm{~b}$ & $134.8 \mathrm{ab}$ & 47.6 \\
SSC & $\mathrm{M}$ & $8.3 \mathrm{a}$ & $6.5 \mathrm{a}$ & $7.3 \mathrm{a}$ & $6.3 \mathrm{a}$ & 2.1 \\
& $\mathrm{P}$ & $6.4 \mathrm{a}$ & $5.2 \mathrm{a}$ & $6.3 \mathrm{a}$ & $6.4 \mathrm{a}$ & 1.6 \\
TA & $\mathrm{M}$ & $0.9 \mathrm{a}$ & $0.8 \mathrm{ab}$ & $0.7 \mathrm{~b}$ & $0.7 \mathrm{ab}$ & 0.1 \\
& $\mathrm{P}$ & $0.9 \mathrm{a}$ & $0.7 \mathrm{~b}$ & $0.7 \mathrm{~b}$ & $0.9 \mathrm{a}$ & 0.1 \\
SSC/TA & $\mathrm{M}$ & $9.8 \mathrm{a}$ & $8.5 \mathrm{a}$ & $11.6 \mathrm{a}$ & $8.9 \mathrm{a}$ & 3.0 \\
& $\mathrm{P}$ & $7.1 \mathrm{~b}$ & $7.5 \mathrm{ab}$ & $9.1 \mathrm{a}$ & $7.1 \mathrm{~b}$ & 2.0 \\
\hline
\end{tabular}

${ }^{\mathrm{z}} \mathrm{LSD}$ values, for comparison of cultivar and selection means, were calculated from separate analyses of variance for 15 cultivars and advanced selections in the advanced matted row production system (M) and 25 in the plasticulture system $(\mathrm{P})$.

in May 2002. Fruit harvest was between 2 to 15 July 2003 with a peak date of 8 July, much later than the Iowa standard late-season cultivars, 'Jewel' or 'Winona'. 'Ovation' yield in 2003 was comparable to yields of 'Northeaster'.

New Jersey. 'Ovation' was evaluated with eight other genotypes, including the cultivars 'Chandler' and 'Camarosa', in a fumigated plasticulture production system in 2003. 'Ovation' produced the largest fruit at $26.6 \mathrm{~g} /$ fruit, and fruit were attractive and flavorful. Yield of 'Ovation' at $13,022 \mathrm{~kg} \cdot \mathrm{ha}^{-1}$ was not significantly different from the highest yielding cultivar, 'Chandler' at 16,562 kg.ha ${ }^{-1}$. Rutgers Cooperative Extension is recommending 'Ovation' to New Jersey growers using a plasticulture production system as a late-season cultivar to follow 'Chandler'.

New York. 'Ovation' was compared in 2003, in traditional matted-row production near Geneva, with 'Clancy' and 'L'Amour', two new releases from Cornell University, in addition to 'Annapolis', 'Jewel' and 'Honeoye'. The fruiting season for 'Ovation' finished 9 July and was the latest of the cultivars tested, though not significantly different from 'Clancy'. No significant differences were detected for fruit yield or size among the genotypes tested.

Ohio. 'Ovation' was evaluated with 'Earliglow' (plugs and fresh-dug), 'Avalon', 'Allstar', and the North Carolina State University selection NC95-08 in raised beds covered with embossed black plastic and irrigated with T-tape using emitters at $30 \mathrm{~cm}$ apart. This system is relatively new to Ohio. In August and September 2001, plug plants were established at two grower locations: $24 \mathrm{~km}$ south of Columbus (Grower A) and $97 \mathrm{~km}$ north of Columbus (Grower B). 'Ovation' yield was second only to 'Allstar' at both locations. 'Ovation' had the largest berry size of any cultivar tested, and had only $23 \%$ of its berries harvested when 'Allstar' had 74\% of its berries harvested. 'Ovation' had excellent color; flavor was considered equal to or better than that of 'Allstar' at Grower B's location. 'Ovation' can be an outstanding late ripening cultivar for Ohio growers trying this production system.

Pennsylvania. 'Ovation' was evaluated in traditional matted-row production with 27 other cultivars and selections near Rock Springs in 2003. 'Ovation' established very well, produced multiple crowns and runners, and filled the plots well before winter of the planting year. 'Ovation' fruited later than 'Jewel' in this environment, and the fruits were attractive though average in size at $11.5 \mathrm{~g} /$ fruit, similar to mid-late season cultivars 'Jewel' and 'Winona', and late season cultivars 'Yamaska' and 'Saint-Laurent d'Orléans'. 'Ovation' was the best all-around choice for a late-season cultivar in this environment compared with late-season cultivars 'Idea', 'Yamaska', and 'Saint-Laurent d'Orléans', the only other cultivars to fruit as late in the season as 'Ovation'.

Wisconsin. 'Ovation' was evaluated at River Falls with 43 other cultivars and selections in traditional matted-row production in 2003. 'Ovation' was consistent in that it fruited late in this environment, though, interestingly, 'Jewel' fruited with midseason cultivars and averaged 10.3 g/fruit. 'Ovation' fruits were among the largest third in this environment, averaging $13 \mathrm{~g} /$ fruit. However, 'Ovation' $\left(1,740 \mathrm{~kg} \cdot \mathrm{ha}^{-1}\right)$, 'Allstar' (2,643 kg.ha $\left.{ }^{-1}\right)$, 'Northeaster' $(4,190$ $\left.\mathrm{kg} \cdot \mathrm{ha}^{-1}\right)$, and 'Jewel' $\left(9,666 \mathrm{~kg} \cdot \mathrm{ha}^{-1}\right)$ all yielded much lower than at other locations and do not appear to be adapted to this environment. The high-yield standard cultivar for the area has been 'Cavendish' $\left(17,869 \mathrm{~kg} \cdot \mathrm{h}^{-1}\right.$ in 2003).

\section{Fruit Nutritional Characteristics}

In 2002, 'Ovation' was compared with 29 other strawberry cultivars and selections for the soluble solid content, titratable acid content, total anthocyanin content, total phenolic content, and oxygen radical absorbance capacity (ORAC) according to Wang et al. (2002). Twenty ripe fruits with well-developed red color were harvested around 9:00 AM from each of two plots each grown in the plasticulture and advanced matted-row production systems in Maryland. Fruit were bulked and processed for each plot separately. Values were subjected to an analysis of variance for each production system using the PROC GLM command of SAS 8.2 software (SAS Institute Inc., 1999). For each production system least significant difference values were calculated for differences between cultivars and selections (Table 3 ) for each of traits evaluated. In both production systems, 'Ovation' was among the highest in ORAC, total anthocyanins content and total phenolics content. The high content of these antioxidants could be an added benefit to growers with customers interested in the potential health benefits of fruit.

\section{Disease Resistance}

Red-stele. 'Ovation' survived being screened as a seedling to a mixture of $P$. fragariae races A-1, A-2, A-3, A-4, and A-6 in a greenhouse bench test (Scott et al., 1975). However, it could not be re-evaluated for resistance to red stele due to a loss of the $P$. fragariae isolates.

Foliar diseases. After fruiting, 'Ovation' often develops symptoms of powdery mildew, caused by Sphaerotheca macularis (Wallr. ex Fr.) Jacz. f. sp. fragariae, to about the same extent as 'Earliglow'. However, the disease does not seem to negatively affect plant vigor under Beltsville field conditions. Other than powdery mildew, plants are free of significant foliar disease in spring and fall evaluations.

Anthracnose crown rot. Young runner plants of 'Ovation', 'Chandler' and 'Pelican' were rooted in $10-\mathrm{cm}$ pots under intermittent mist in November 2002. After 2 weeks the rooted plants were transplanted to $10 \times 10 \mathrm{~cm}^{2}$ plastic pots containing a 1:1 (by volume) mixture of JiffyMix (JPA, West Chicago, Ill.) and pasteurized sand, and grown from November 2002 through April 2003 in a greenhouse maintained at $28^{\circ} \mathrm{C}$ day $/ 18^{\circ} \mathrm{C}$ night $\pm 6^{\circ} \mathrm{C}$ with a 16 -h photoperiod. To encourage vegetative growth, flowers were removed during establishment. Older leaves, runners, and flowers were removed 1 to $7 \mathrm{~d}$ before inoculation, and three or four young leaves remained on each plant at inoculation. Inoculum of Colletotrichum acutatum J.H.Simmonds isolate Goff was prepared as described in Smith and Black (1987). Four plants each of 'Ovation', 'Chandler', and 'Pelican' were inoculated with C. acutatum, and three plants each were inoculated with sterile distilled water on 30 Apr. 2003. Plants in each treatment group were inoculated and incubated separately to prevent contamination, and plant genotypes were randomized within treatment. A second set of plants was similarly inoculated 6 May 2003.

Disease development based on lesion length and crown rot symptoms was assessed $30 \mathrm{~d}$ after inoculation (Smith and Black, 1987). Disease severity was rated on a standardized scale of 0 to $6(0=$ healthy plant with no visible symptoms $1=$ petiole lesions $<3 \mathrm{~mm}$ long; $2=$ petiole lesions 3 to $10 \mathrm{~mm}$ long; $3=$ petiole lesions $>10$ to $\leq 20 \mathrm{~mm}$ long; $4=$ petiole lesions $>20$ mm long; 5 = youngest leaf wilted; $6=$ dead plant). Because the disease scores are less than ten, they were transformed by taking the square root of the rating +0.5 (Steel and Torrie, 1980) Analysis of variance (SAS 8.2, SAS Institute Inc., 1999) indicated no significant difference between sets or replications within sets, and no interaction between sets and either genotypes or treatments. 'Ovation' plants had a significantly lower anthracnose disease score than the 'Chandler' plants and a significantly higher score than the 'Pelican' plants. The mean untransformed 
30-d disease score for 'Ovation' was 3.6 (susceptible), for 'Chandler' was 4.9 (susceptible), and for 'Pelican' was 1.3 (resistant). Therefore, although we have not observed anthracnose disease symptoms on 'Ovation' plants in the field during 12 years of evaluation, it is possible that 'Ovation' plants may be infected by the anthracnose pathogen when conditions are conducive for disease development.

\section{Availability}

'Ovation' plants were increased by micropropagation from virus-indexed mother stocks, and were released to nurseries on 9 Jan. 2003. Contact Kim Lewers for a list of nurseries that propagate 'Ovation'. In addition, genetic material of this release has been deposited in the National Plant Germplasm System as accession PI 634800 and is available for research purposes, including development and commercialization of new cultivars. It is requested that appropriate recognition be made if this germplasm contributes to the development of a new breeding line or cultivar.

\section{Literature Cited}

Ashley, M.V., S.M.N. Styan, K.J. Craft, K.L. Jones, K.A. Feldheim, J.L. Fessler, K.S. Lewers, and T.-L.Ashman. 2003. High variability and disomic segregation of microsatellites in the octoploid Fragaria virginiana Mill. (Rosaceae). Theor. Appl. Genet. 107:1201-1207.

Black, B.L., J.M. Enns, and S.C. Hokanson. 2002 A comparison of temperate-climate strawberry production systems using eastern genotypes.
HortTechnology 12:670-675.

SAS Institute Inc. 1999. SAS online doc. Version 8. SAS Institute Inc., Cary, N.C.

Scott, D.H., J.L. Maas, and A.D. Draper. 1975 Screening strawberries for resistance to Phytophthora fragariae with single versus a composite of races of the fungus. Plant Dis. Rptr. 59:207-209.

Smith, B.J. and L.L. Black. 1987. Resistance of strawberry plants to Colletotrichum fragariae affected by environmental conditions. Plant Dis. 71:834-837.

Steel, R.G.D. and J.H. Torrie. 1980. Principles and procedures of statistics, p. 234-235. McGrawHill, New York.

Wang, S.Y., W. Zheng, and G.J. Galletta. 2002 Cultural system affects fruit quality and antioxidant capacity in strawberry. J. Agr. Food Chem. 50:6534-6542. 